\title{
Circuit
}

Musiques contemporaines

\section{Jouer et rejouer la musique de Garant} Performing and performing again the music of Garant

\section{Bruce Mather}

Volume 7, numéro 2, 1996

Serge Garant

URI : https://id.erudit.org/iderudit/902173ar

DOI : https://doi.org/10.7202/902173ar

Aller au sommaire du numéro

Éditeur(s)

Les Presses de l'Université de Montréal

ISSN

1183-1693 (imprimé)

1488-9692 (numérique)

Découvrir la revue

Citer cet article

Mather, B. (1996). Jouer et rejouer la musique de Garant. Circuit, 7(2), 11-12.

https://doi.org/10.7202/902173ar d'utilisation que vous pouvez consulter en ligne.

https://apropos.erudit.org/fr/usagers/politique-dutilisation/ 


\section{Jouer et rejouer la musique de Garant} Bruce Mather

Dix ans après sa disparition, on se rend compte à quel point Serge Garant nous manque comme compositeur, chef d'orchestre, professeur et animateur. C'est surtout durant les dix premières années de la SMCQ que j'ai collaboré avec lui, alors que j'occupais les fonctions de trésorier, bibliothécaire et pianiste de l'ensemble. J'élaborais la programmation avec lui. 
A chaque fois que je dirige une œuvre de Garant avec l'Ensemble de musique contemporaine de la Faculté de musique de l'université McGill (trois fois Circuit III pour 18 instruments, deux fois Amuya pour percussion et orchestre de chambre ainsi que le Quintette), je dis aux élèves: «Voilà de la véritable musique moderne. " Si j'inscris souvent ses œuvres au programme de l'ensemble, c'est d'abord à cause de leurs grandes qualités, mais aussi parce que la plupart sont de difficulté moyenne, donc accessible à de bons instrumentistes qui ne sont pourtant pas des virtuoses.

Serge était pour moi la « conscience " de la musique contemporaine. Je me souviens spécialement d'entretiens que j'ai eus avec lui en janvier 1985, alors que je l'accompagnais à Rome, où il a dirigé le Nouvel Orchestre philharmonique de Radio-France dans des œuvres de Vivier, Tremblay, Garant et moimême. Il était consterné et découragé par l'évolution de la musique contemporaine. II disait: "La musique contemporaine a fait fausse route, car trop de compositeurs ne font que des pastiches de vieille musique ou de la musique répétitive ennuyeuse. II faudrait que les jeunes étudient les chefs-d'œuvre de Schönberg, Webern, Berg, Stravinsky et Varèse afin de découvrir la musique moderne."

II faut jouer et rejouer la musique de Garant, qui témoigne des grandes valeurs qu'il défendait.

4 avril 1996 